\title{
Politicizing Corporate Social Responsibility: A Triple Bottom Line Perspective of Kitex's Twenty20 Association
}

\author{
Srinsha $\mathrm{K}^{1}$, Luqman Thazhathe Peedikakkal ${ }^{2}$ \\ ${ }^{\prime}$ (Sub-Editor, South Live News Portal, Kerala, India) \\ ${ }^{2}$ (Guest Lecturer, Department of Journalism and Mass Communication, University of Calicut, Kerala, India)
}

\begin{abstract}
Kitex Limited is a growing corporate in Kerala and it is one of the largest private sector employers in the state. Kitex- Twenty 20 association is a group formed by the company to engage in active politics. In 2015, the group entered into active politics and won 17 out of 19 seats in Kizhakkambalam panchayath of Ernakulam district in Kerala, India. The aim of the case study is to understand the various Corporate Social Responsibility activities of Kitex- Twenty 20 association and to check whether these activities helped them to win the local body elections in 2015. The present study is done on the basis of Triple Bottom Line theory of John Elkington. That is, as the theory suggests, the researcher tries to analyse the economic, social and environmental related CSR activities of the company. It is found that the company has done a series of CSR activities effectively and it paved the way for the success of the association in the election. The study also reveals that Kitex Ltd is in the forefront in social activities rather than in economic and environmental activities.
\end{abstract}

Keywords - Companies act, Corporate Social Responsibility, Kitex Ltd, Triple Bottom Line Theory, Twenty20 association.

\section{INTRODUCTION}

People always dream of a system which prioritizes equality and justice as its base, and at last with an effort prolonging centuries, we have initiated a revolutionary system called Democracy. Still, struggles and strikes go on around the world for a scheme 'for the people, by the people and of the people'. Of course, Democracy has drawbacks and it's incomplete. However, a democratic structure is willing to inculcate new ideas and concepts to make it complete and perfect. Obviously, this makes people from all around the world love and admires democracy. India, after years of struggle, has established a democratic governing system, which serves its billion populations. Unfortunately though, now billionaires and millionaires have a sinister influence over the governing bodies. Further the bigwigs of corporates are being spring the deviance and discrepancy among the people as well. Corporate Social Responsibility is a much debated and discussed topic across the world. The concept has been prevalent since industrialization. However, in the $21^{\text {st }}$ century the concept has widened along with the business of corporates. Many countries have adopted mandatory CSR policy to bridge the gap between the have and have not. The concept of CSR is applauded and denounced simultaneously. Many scholars have appreciated the concept of CSR while many saw this as a concept which lack clarity and coherence. A fundamental argument against CSR is that it is not helping the disadvantaged as like it proclaims. Milton Friedman opposed CSR by saying that the business firms operate merely on the basis of profit and their one and only responsibility is to make profit by staying within the rules of the game that is to engage in open and fair competition without deception and fraud. Mullerat suggested that CSR helps a firm to project a positive image by doing very little (Freidman, 1982).

\subsection{Anna Group}

Anna group was founded by M C Jacob, one of the famous entrepreneurs in Kerala in 1968. The company entered into the market with its initial venture- Anna Aluminium. The company now enjoys a high profile across the world. Anna Aluminium was founded by M C Jacob with a total of eight workers. Now it is one of the largest private sector employment providers in the state. The company has an annual turnover of INR 1200 crores. The group enjoys a monopoly in the market of utensils, aluminium sheets and vessels. Chakson pressure cooker, a product of Anna aluminium group surmounted the market for pressure cooker in Kerala and still it is enjoying the fame. The products of Anna group have market in all over India. Besides, the company enjoys market in Middle East, Australia, and USA. Later the group enlarged its prospects through multidimensional products. After the success of Anna aluminium products, the company registered Kitex Limited, a textile manufacturing unit in 1975. In 1979, textile production initited at Kitex Ltd. In the same year, the company registered for 'Saras' spices and food product. 'Chakson' brand pressure cooker was introduced in the year 1993 and later in 2000 the company manufactured 'Scoobeeday' bags which acquired a good share of the 
school market in Kerala. In 2007, Kitex group came with two new products- Agna Adonis inner wear and Scoobee LooBee for Kids. In 2008, the company introduced 'Trawellday', bags designed for travel purposes.

Sabu. M. Jacob, son of M.C Jacob, is the managing director of Kitex Limited since 2006. He took the leadership of the company following the retirement of his father M.C Jacob.

\subsection{Twenty20 Kizhakkambalam}

The community development activities of Anna group were carried out in the aegis of Kitex GroupTwenty 20 Kizhakkambalam. Twenty 20 is actually a charitable trust registered for employing the CSR of Kitex group.

\subsection{CSR and Kitex}

'Reaching out to undeserved community' is the motto of Kitex's CSR initiatives. Kitex Garments Limited which believes in trusteeship policy proclaims; their CSR initiatives are meant for bringing a significant difference in the life of the undeserved community in which they operate. It is this perception which motivated Kitex to come down in favour Kizhakkambalam panchayath to impart their CSR initiatives (Kitex, 2012).

\subsection{The Entry of Kitex in Mainstream Politics}

Kitex Garments- Twenty 20 association came into existence in the year 2013. The association originally started as a charitable organization registered under the Travancore- Cochin Literary, Scientific and Charitable Societies Act, 1955. The association constitutes a well-structured organizational structure, which places Sabu. M. Jacob as its head. At the time of Twenty-20's commencement, Kizhakkambalam panchayath was ruled by the congress government. As per the 2010 local body election trends, congress had secured 15 seats out of 21 with commendable majority. LDF which was in power in the state during the time had downplayed the election only with 2 seats. Coming to 2015, the political scenario of Kizhakkambalam witnessed a paradigm shift in all spheres. The outcomes of this political change audibly echoed in the local body election. Twenty 20 Kizhakkambalam, a CSR initiative of Kitex group had swept the panchayath with 17 seats out of 19 (Commission, 2015). It was a setback for both the Congress and LDF. The victory of Congress has narrowed to one seat from 15, and the Left Democratic Party completely scrammed from the election scene. The Twenty 20 wave in Kitex has affected both LDF and UDF, however, for UDF it was a matter of reputation as they were the ruling party in the panchayath.

\subsection{Theoretical Framework}

This case study was conducted on the basis of Triple Bottom Line theory. The term, 'Triple Bottom Line' was coined by John Elkington in 1994. He was the founder of a British consultancy called 'Sustain Ability'. According to him, companies must constitute three levels of strategies, namely 'profit', 'people' and 'planet'. 'Profit' is the measure of the financial and economic aspect of a company. 'People' stands for the measurement the social contribution, and the concept 'planet' is introduced to analyse the ecological contribution of the firm for sustainability. (Elkington, Enter the Triple Bottom Line, 1994). In short, Triple Bottom Line or TBL measure the environmental, social, and economic aspect of a firm's contribution over a period of time. TBL can be considered as the manifestation of the balanced scoreboard, which take account of the full cost of doing business. Thus, it is considered as an accounting framework, which incorporates three dimensions of performance: social, environmental and economic. The sustainability of a firm can be measured using Triple Bottom Line Theory.

\section{REVIEW OF LITERATURE}

Governance of Mandated Corporate Responsibility: Evidence from Indian Government Owned Firms, (8 August 2015), a study conducted by Nava Subramaniam, Monika Kanssal and Shekhar Babu focuses on the change emerged after implementing mandatory CSR for central government owned firms in 2010. It looks at CSR in the lime light of Companies act, 2013. The results were spread into separate categories including Politics and CSR Policy, CSR management structures, CSR management process, service delivery and output vs outcomes. The majority of the private companies were reticent towards compulsory CSR. The ambiguities related to the law intensified this reluctance. CSR initiatives undertaken by public enterprises were found to be aligned with community development. The conceptual framework of the study is based on the Law of Governance (LOG) developed by Lynn. The study is published by Springer. The study corporate social Responsibility and Corporate Governance: Role of Context in International Setting (June 2014, volume 122, issue 1) is carried out Suzanne Young by referring three countries Australia, UK and India for two years. Information related to governance, which collected from shareholders, stakeholders and other important administrators of the company. In order to explore the relationship between corporate governance and CSR the researcher analyzed the major factors that play a direct role in the establishment of this relationship. The study 
successfully found that corporate governance and CSR has a direct connection. Does Corporate Social Responsibility Influence Firm Performance of Indian Company (September, 2010 Volume 95, issue 4) is a research carried out Supriti Misra and Damodar Suar, published in the Journal of Business ethics. The study investigates whether there exist any relation between corporate social responsibility of a firm to its financial and non-financial performance. For this, the researcher collected information regarding CSR and NFP from 150 senior level Indian managers including CEO through questionnaire survey. The study shows that responsible CSR practices are directly associated with the profit. Capitalism and Democracy in the $21^{\text {st }}$ Century: From the Managed to Entrepreneurial Economy (2000), investigates the economic shift of developed country from managed to entrepreneurial economy. David.B.Audretsch and A. Roy Thurik jointly carried out the study.

\section{OBJECTIVES AND METHODOLOGY}

- To understand the economic, social and environmental aspects of the Corporate Social Responsibility activities carried out by Kitex Ltd. under the label of Twenty20 at Kizhakkambalam Grama Panchayat of Ernakulam district, Kerala, India.

- To find out whether the CSR activities of Kitex Ltd helped them to gain local body elections at Kizhakkambalam.

\subsection{Case Study}

A detailed case study using the Triple Bottom Line Theory (TBL) helped in understanding the various Corporate Social Responsibility (CSR) activities carried out by Twenty20 in Kizhakkambalam. The 'Triple Bottom Line' theory has been used to probe into the case to measure the sustainability or viability of the economic, social and environmental issues in the region.

\subsection{Secondary Data Collection}

The researcher relied on the Kitex Group, Twenty20 association at Kizhakkambalam Panchayath to gather the data regarding the CSR activities of the company. To collect the finance-related information, the researcher used the CSR report of the company, which was prepared on an annual basis. The company's website is another important source of secondary data gathering.

IV.

ANALYSIS

'Compassionate care' -under this tag line Kitex Group has made a landmark of activities at Kizhakkambalam grama panchayath of Ernakulam district in Kerala. The group affirms that through the CSR activities, they are bringing up their interest to build a better society with high life standards. The phrase 'compassionate care' is carefully designed to signify the care and affection of the company towards the people of Kizhakkambalam.

\subsection{CSR Activities in Economic Sector}

Self-employment scheme and Twenty 20 market are the important activities taken by Kitex group in the economic sector. Pointing at the external audience, Kitex Group has introduced self -employment schemes. These are anticipated to offer fiscal stability and self-sufficiency for economically backward people. The Twenty20 market, another important edge in economic sector offered subsidized products at half market price for the residents of Kizhakkambalam.

The economic activities conducted out by Kitex group are listed below.

\begin{tabular}{|l|l|}
\hline Services & Short description \\
\hline \multirow{4}{*}{ Self- employment } & $\begin{array}{l}\text { Self-employment measures were taken to improve financial security for the } \\
\text { poor and disadvantaged }\end{array}$ \\
\cline { 2 - 2 } & Street vendors were opened for Two persons \\
\cline { 2 - 2 } & The lottery-selling facility was arranged for 12 residents. \\
\cline { 2 - 2 } & Eight Self -employment Organizations were set up. \\
\cline { 2 - 2 } & Facilities for animal husbandry were opened in houses. \\
\hline Food security programme & Subsidized food products distributed through Twnety20 market. \\
\hline
\end{tabular}

Table 1: List of economic related CSR

Through the analysis of the economic related CSR of the Kitex group the researcher found that the company has given a greater emphasis to the economic sector. Twenty 20 market, one of the widely discussed economic initiatives of the company has given wider reach for CSR based initiatives of the firm. Moreover, it helped the firm to create a favourable image and reputation among the public. Fiscal advantage and the quality of products attracted a large section of the people towards the market; subsequently this gave a wider reach for 
the economic initiative of the company. The market helped the company to attain a favourable reputation within the people coming from different sectors. To use the service on the Twenty 20 card, customers require Twenty 20 card which is issued directly from the company. Hence it is evident that the card based allocation system for the market linked the entire panchayath with the company and helped the firm to exercise its power over the society through the Twenty 20 card. The case study analysis found that after the election, the company has cancelled the Twenty 20 card for the people who opposed the Kitex group.One has to note that these activities were carried out by the company at a time when the public distribution system of the government failed to serve the people. Even the poorest section of the population didn't get any benefits from the public distribution system and they suffered a lot owing to the price hike. Thus, for the people it became inevitable to depend the Twenty 20 market. The market effectively convinced the people that Twenty 20 is the only remedy for the people's problems and it attracted a mass number of people towards the Twenty 20 party. Instead, beginning the market unlike its usual activities targeting a limited number of people, Twenty 20 aimed at the entire panchayath. The success of the market can be considered as one of the effective reasons for their growth as a political party in the Kizhakkambalam panchayath.

The self-employment projects are the next noted enterprises of Twenty20 in the economic sector. It helped the company to boost its image among the general public. Through the self-employment scheme, the company provided jobs for many people and created a good will in front of the public. The positive reputation was further utilized for the election as well. The same has happened in the case of the employees of the company as well. Twenty 20 framed the self-employment project centering the women; this has further helped them to create a favourable impression around the society. The project offered a way of living for the women; consequently this made women to trust the company and to take a position favourable for them.

Seeing the financial benefits, the company linked the self-employment enterprises opened for the women with the Twenty 20 market. Thus, through the market the self-employment initiatives got the publicity and market. The economic enterprises opened by the company seem to align more with the social sector rather than on the financial aspect.

\subsection{Social Related CSR}

Twenty20 mainly emphasized on implementing activities in social sector rather than environmental or economic sectors. The majority of the social undertakings were framed aiming at the village community. All the categories of the people were considered eligible for the benefits and schemes proposed by the company based on certain criteria. The following are the main initiatives taken by Twenty 20 in the social sector.

Table 2: List of social related CSR

\begin{tabular}{|l|l|}
\hline Services & Short Description \\
\hline Free food delivery & Free food delivery for poor people at Kizhakkambalam Nagar. \\
\hline Education & $\begin{array}{l}\text { Distributed school bags, renovation of toilets, measures were taken to improve } \\
\text { educational standards. }\end{array}$ \\
\hline Drinking water & Distributed drinking water to ensure the food security. \\
\hline Vegetable Fests & Vegetables Fests are organized during the festive seasons at a low price. \\
\hline \multirow{5}{*}{ Health and medical care } & Organized medical camps at Kizhakkambalam. \\
\cline { 2 - 2 } & Offered financial assistance to 1890 surgeries. \\
\cline { 2 - 2 } & 9 surgeries were performed for the disadvantaged infants. \\
\cline { 2 - 2 } & Financial assistance for dialysis patients. \\
\cline { 2 - 2 } & Free ambulance service. \\
\cline { 2 - 2 } & Post death assistance. \\
\hline Steps to control epidemics & Fogging and related measures to control the outbreak of diseases. \\
\hline Disaster Relief services & Financial helps were provided for the draught and flood affected areas. \\
\hline Anthrax control & Offered help for the farmers when the cattle are infected with anthrax. \\
\hline Crop Destruction & Compensation was provided to the farmers for crop destruction. \\
\hline Road construction & 15 roads which connect Kizhakkambalam with other places were widened. \\
\hline Sports Sector & Programmes and assistance for youth and teenagers who are interested in sports. \\
\hline Relief fund & Relief funds are offered for disaster affected people of the village. \\
\hline Mosquito control & Measures to prevent the growth of mosquitoes. \\
\hline Prevention of corruption & Measures were taken to initiate corruption-free governance. \\
\hline Renovation of Worship places & Temples, mosques and churches were renovated under this scheme. \\
\hline
\end{tabular}

Twenty 20 has given greater importance to the social sector. On tracking the activities carried out by them, it can be understood that the CSR activities of Kitex group were mainly concentrated and connected with the people and their life. The sheer aim behind the societal initiatives was to bring people close to the company and Twenty 20 through regular interference with their problems. Aiming at this, help was provided for every section of the population. Individual care and attention was offered for the people and the company comes up with instantaneous remedial measures for the problems of the people. This helped the firm to intensify the belief of people in their organization. The social activities initiated in various sectors helped Twenty 20 to gain people's trust and support. Twenty 20 considered every section of the people equally towards their programmes. 
They provided financial help and support for the poor and downtrodden; at the same they came up with remedial measures for the problems of middle class and offered promises of high-level infrastructure to the upper class. The company has appointed MSW workers in every ward to study about the demography and to understand the problems of the people. This type of strategies used by the firm is powerful to convince the people about their importance. The company spent a huge share of their money for the societal activities; similarly more numbers of activities were carried out by centering social sector. Equal distribution of priority helped Twenty 20 to gain support from different sections of the society. Obviously, this is one of the reasons behind the unbreakable majority of Twenty20 in the panchayath.Protests and rallies were organized by the company against the previous governing body of the panchayath. This type of activities is not so common in CSR, but here the Kitex group has arranged a number of mass protests. The governing body of the panchayath was mainly targeted during the protest. Similarly the Twenty 20 has also come up with drug free initiatives which helped them to gain mass support especially from women. This indicates that Twenty20 has extended its activities beyond the CSR, especially in the case of social sector.

\subsection{Environmental Activities carried out by Kitex}

Table 3: List of environmental related CSR

\begin{tabular}{|l|l|}
\hline Services & Short description \\
\hline \multirow{5}{*}{ Agriculture } & Participatory group farming \\
\cline { 2 - 3 } & Seasonal vegetable plant cultivation and multi- crop harvesting \\
\cline { 2 - 2 } & Poison free vegetable initiative \\
\cline { 2 - 2 } & Twenty20 Green Kizhakkambalam programme \\
\cline { 2 - 2 } & Farming on various lands \\
\cline { 2 - 2 } & Free grow bag distribution \\
\cline { 2 - 2 } & Harvesting fest \\
\cline { 2 - 2 } & Introduction of modern technology and equipments in agriculture \\
\hline
\end{tabular}

The company overtook these activities comprehensively in the panchayath. Separate programmes were designed for different areas, wherein, a ward-wise classification can be seen in the allocation of programmes. Exclusive proposals were also submitted to the government schools to start 'go green' initiatives.

In a meticulous analysis, it can be understood that the company mainly concentrated on social side rather environmental or financial. The TBL analysis suggests Twenty20 has done a little for the environment compared to financial and social sector. Agriculture is the widely projected environmental responsibility of the Kitex group; on the other side this widely publicized environmental activity is having much impact on the social side rather than environmental. Twenty 20 was formed at a time when Kitex Ltd was accused by the public for not having proper waste management plants. Owing to this, the former panchayath president had denied license for them to start a new plant in the village. This dispute between the panchayath authorities and the company had created a hostile condition for the operation of the company. It is actually during this time the company came with the CSR programmes in the panchayath. The company has been criticized for not being environmentally responsible. Owing to this the action council has filed cases against the company. But yet they have not taken any measures to tackle the environmental problems created by the plant. Instead, they tried to hide this issue using the social and economic CSR based programmes.

The company is mainly accused for the unscientific waste treatment and management. The waste from the company is sending outside through a pipe of around $50 \mathrm{~cm}$ wide. This water waste reaches in the VilangThazathepeedika pond and subsequently spread throughout the area. Similarly, the company is also blamed for sending the water waste from dyeing unit into Chelakkulam- Chirangara pond. Similarly, the company accompanies around 7000 employers in Kizhakkambalam panchayath. But the organization doesn't have proper facilities for the sanitary waste management. Sending the waste into natural resources like the river and the pond is affecting the life of the people seriously. Similarly, they are blamed seriously for not re-using the water through recycling. The action council formed says that this has created water scarcity in the location which company lies. Systematic analysis of the date of the implemented programmes helped the researcher to find out that social service aiming at the local community was implemented by the Kitex following the widespread protest from people's part. In order to counter this allegation related to improper disposition of waste, the company came out with the social service scheme and eventually spread it across the panchayath. A number of mass protests were organized targeting the local body authorities. The activities imparted by Twenty 20 got huge public support which gave them the confidence to take part in the local body election.

Twenty20 spins out the election at Kizhakkambalam with a stunning majority. This emphasizes that the CSR activities of the company were powerful enough to get the support of the people. Yet it is impossible to say that it is mere CSR criteria which take the people along with Twenty20. A majority was unaware about CSR and the company has not mentioned about it anywhere other than their website. Even the election manifesto of

Twenty20 has not used the word Kitex or CSR at anywhere. Rather, they used the enlarged image of Sabu. M. Jacob. During these times, efforts were being made to convert Sabu. M. Jacob as an opinion leader 
among the people. The projected image of Sabu M. Jacob has also helped the company to gain the intended result.The case study analysis helped the researcher to identify that the CSR activities carried out by Kitex group at Kizhakkambalam panchayath helped them improve the corporate reputation among stakeholders. It helped the company in the process of image building among its external audience. The case depicts that if CSR activities are effectively carried out it has a scope to create not only economic, social, and environmental results, but also it is possible to create political result as well. The Kitex- Twenty20 association used their CSR based programmes to politically influence the people of Kizhakkambalam. The incumbency factor from the mainstream political parties helped them to attain their goals easily. The success of Kitex also indexes the changing political attitude of the people as well.

On analyzing the activities carried out by Kitex in different sectors, it can be understood that the company has not followed a criteria of sustainability based on the triple bottom line theory. They have given much importance to areas of living that are primly connected with the people. Initiatives in farming, housing, health and medical care are relevant in that term. About $90 \%$ of the activities carried out by the company stand in the social sector. The activities of the company on environment side were rather unsatisfactory and disappointing; this in turn has created a protest from the people. The group has spent a huge amount in Kizhakkambalam as part of their CSR. This has helped them to attain a favourable corporate reputation among the public.

\section{DISCUSSION AND CONCLUSION}

We have been hearing about the consequences of a corporate-influenced administration for years. And, here in Kerala, Kitex group has materialized the concept of corporate governance for the first time. It is their planning and organized CSR initiatives which helped them to attain this much acceptance from the people. The case demands an extensive research and understanding as this trend is rarely seen, particularly in a state like Kerala, which is well-known for keeping a political conscience and understanding. The company, unlike traditional CSR practices, has conducted rallies, strikes and protests against the previous panchayath body by canvassing the people. Still, they haven't done anything to address the pollution-related issues caused by them. The bulk money raised by the company, in fact, dissolved the Action Council itself. It is to be noted that a good proportion of the population living near the locality, where the company operates, suffer from the pollutionrelated issues caused by the industrial unit of the company. However, the election results proved that a good majority of the panchayath's population favours the company. The people consider the help offered by the company as a blessing, and feel really indebted to Sabu. M. Jacob for this.Presently, at Kizhakkambalam, the elected representatives receive a monthly salary from the company. Thus, the representatives are acting more like employees rather than representatives of the people. In such a society, democracy will be in endangerment, as what is happening right now in Kizhakkambalam. The incumbency factor from the political parties is another reason for people to trust such organizations, and it indicates a new trend that might evade the society in recent future. It is clear that CSR can be effectively used for building an organisation's reputation among the public. The case of Kizhakkambalam takes this to the next level to prove that, if exercised effectively, CSR is powerful in the political structure as well.

\section{REFERENCES}

[1] Freidman, M. (1982). Capitalism and Freedom. Chicago : The University of Chicago Press Ltd London.

[2] Kitex. (2012). Retrieved from Kitex Garments Ltd: http://kitex.annagroup.net/

[3] Commission, S. E. (2015, December). Keral Local Polls. Retrieved from Trend Kerala:http://lsgelection.kerala.gov.in/lbtrend2015/views/lnkResultsGrama.php

[4] Elkington, J. (1994). Enter the Triple Bottom Line.

[5] Elkington, J. (1997). Cannibals with Forks. In J. Elkington, Cannibals with Forks. Captstone Publishing Ltd Oxford.

[6] Whelan, G. (2015, January). The Political Perspective of Corporate Social Responsibility: A Critical Research Agenda. iness Ethics Quarterly, 22(04), 30. doi:10.5840/beq201222445

[7] Supriti Mishra, Damodar Suar. (2010). Does Corporate Social Responsibility Influence Firm Performance of Indian Companies? Journal of Business Ethics, 31.

[8] Babu, N. S. (2014, November 27). Governance of Mandated Corporate Social Responsibility: Evidence from Indian Government-owned Firms. Journal of Business Ethics, 21. 